\title{
Polyester Sling Scrotal Cover Induces Oligozoospermia in Normal Indonesian Men
}

Nukman Moeloek

\begin{abstract}
Abstrak
Tujuan penelitian ini adalah untuk mengetahui pengaruh penutupan skrotum dengan poliester terhadap produksi sperma pada pria Indonesia sehat. Penelitian terdiri dari 2 fase, yailu fase kontrol dan fase perlakuan. Sepuluh relawan sehat dan normal memakai poliester penutup skrotum sepanjang hari dan malam selama 24 minggu. Semen dianalisis tiap 3 minggu, sedangkan kimia klinik dan darah dipantau dengan interval 12 minggu. Hasil menunjukkan bahwa konsentrasi sperma, persentase morfologi sperma normal, dan kecepatan sperma menurun di bawah rata-rata nilai normal pada semua subyek dengan 24 minggu pemakaian. Poliester penutup skrotum dapat menekan produksi sperma sampai mencapai oligozoospermia (100\%) pada pria Indonesia. Tidak satu pun subyek yang mengalami azoospermia, dibandingkan dengan studi yang dilakukan di Mesir yang mencapai 100\% azoospermia pada 14 pria.
\end{abstract}

\begin{abstract}
The objective of this study is to ascertain the effects of polyesther sling scrotal cover on sperm production in healthy Indonesian men. This prospective study consisted of 2 phases, i.e., a control phase and treatment phase trial. Ten normal healthy volunteers used polyester sling scrotal cover all day and night for 24 weeks. Semen was analyzed at a 3-week interval, and clinical chemistry and hematology were monitored at a 12-week interval. The results showed that within 24 weeks sperm concentration, percentage of normal sperm morphology, and sperm velocity decreased to below normal range in all subjects. We concluded that polyester sling scroral cover can suppress sperm production to oligospermia in Indonesian men. Not a single subject achieved azoospermia, as compared with in Egypt study that showed $100 \%$ azoospermia in 14 men.
\end{abstract}

Keywords: Fertility, male contraception, spermatogenesis, electrostatic field, thermoregulation, polyester sling.

\section{INTRODUCTION}

Up to now there is no safe, effective, reversible, and acceptable male contraceptive available. Therefore, it is very important to focus in the search of such a male contraceptive. One of the male contraceptives being developed now is the testicular contraceptive.

In one study in Egypt, 14 subjects used polyester sling scrotal cover daily; all subjects developed azoospermia in 139 (SD 20) days.1 This study also showed that no reproductive hormone changes were found. It is assumed that azoospermia is related to: (a) generation of an electrostatic field through the intrascrotal structure; (b) a thermoregulation disturbance. After discontinuing the scrotal sling, the sperm concentration returned to its normal levels within 156 (SD 14) days. It was concluded that a normal male man could achieve

Department of Biology, Faculty of Medicine University of Indonesia, Jakarta, Indonesia azoopermia by using polyester scrotal sling. Use of the sling is safe, effective, reversible, and more importantly it is inexpensive and it was likely to be accepted as a male contraceptive.

On the other hand, in the search of male contraceptive, there has been evidence to conclude that important ethnic differences exist in achieving azoospermia. The injection of testosterone enanthate can result in azoopermia in approximately $50 \%$ of Caucasian men, but may result in $90 \%$ azoospermia in Chinese men. ${ }^{2}$ A combination of testosterone enanthate plus depot medroxyprogesterone acetate results in azoospermia in $70 \%$ Caucasian men, but the same drugs cause in $100 \%$ in Indonesian men. ${ }^{3-8}$

Considering these ethnic differences in achieving azoospermia in male contraceptive research, it is possible that the use of polyester sling scrotal cover will also have a different effectiveness in causing azoospermia in normal Indonesian men. The objective of this 
study was to ascertain the effects of polyester sling scrotal cover on sperm production in healthy Indonesian men.

\section{METHODS}

Fifteen healthy male volunteers aged 21 to 45 years who had at least one child were initially enrolled in this study. Informed consent was obtained from each study subject. The study was approved by the Ethical Committee of Medical Research of the Medical Faculty, University of Indonesia.

All subjects were examined clinically for general health, history of sexual activity, semen analysis, and blood analysis. Semen and blood analyses were performed twice with an interval of 2 weeks. Ten of the volunteers who fulfilled the above conditions and who had the best sperm concentration were selected for study subjects. Volunteers who had history or were found to have active or chronic cardiac, kidney, liver, or prostate problems, were excluded from the study. The sperm concentration was taken twice prior to the study had to be greater than 20 million per $\mathrm{ml}$.

This study was divided into 2 phases, i.e., the first or control phase, and the second or treatment phase.

\section{Control phase}

This phase took one month of observation. Complete history and physical examination were taken from each subject. Two semen samples taken and analyzed with an interval of two weeks, and blood samples were taken from a cubital vein with an interval of 2 weeks for hematology and chemistry analysis. All of the results of semen analysis had to be within normal limits according to WHO Laboratory Manual for the Examination of Human Semen and Semen-Cervical Mucus Interaction. ${ }^{9}$ The sperm velocity was averaged from 25 sperm velocity, which was measured by measurement of sperm velocity to achieve $0.05 \mathrm{~mm}$ distance. $^{10}$

Subjects were analyzed for hemoglobin, hematocrit, white blood cells, platelets, serum glutamic oxaloacetic transaminase (SGOT), serum glutamic pyruvic transaminase (SGPT), blood urea nitrogen and creatinine, as suggested for male contraceptive study. "All blood analysis had to be within normal standard levels. For data analysis the mean of the 2 examinations was presented.

\section{Treatment phase}

In the treatment phase, which took 6 months, all volunteers use polyester scrotal sling with the penis was left uncovered. ' The polyester scrotal sling was used all day and night and replaced everyday. All volunteers were asked to declare the use these sling everyday, and they were checked for using these sling everyday. Each volunteer got 15 polyester sling for a period of 6 months.

All semen samples were analyzed every 3 weeks up to week 24. In addition, blood samples were taken for hematology and chemistry analysis at week 12 and 24 . Data analyses were performed by Anova (one way analysis of variance). $P$ value of less than 0.05 was considered as significant.

\section{RESULTS}

This study was conducted from January 1994 to September 1994. None of the study subject was discontinued for medical reasons, and there were no complaints of change of libido or body weight, or other side effects during the use of polyester scrotal sling. All 10 subjects completed the study. The testicular volume was unchanged throughout the study.

The mean results of semen analyses of 10 men before and during the use of the polyester sling scrotal cover is shown in Table 1. These consisted of semen volume, percentage of sperm motility, the average of 25 sperm velocity to achieve $0.05 \mathrm{~mm}$ distance, sperm concentration, and the percentage of normal sperm morphology. The results of semen analyses before using polyester sling were the mean results of semen analysis 4 and 2 weeks before using the sling, and the results were used for base line data.

The results show that there was no significant difference between semen volume and sperm motility before and during the use of polyester scrotal sling cover ( $p>0.05)$. On the contrary, there were significant differences in the percentage of normal sperm morphology, sperm velocity, and sperm concentration during the period of using polyester scrotal sling $(p<0.05)$.

Figure 1 shows that there were no normal sperm morphology ( $>30 \%$ ) during 24 weeks of using polyester scrotal sling cover. There were also no normal sperm velocity ( $<1.20$ seconds) after 21 weeks of using scrotal sling cover (Fig 2). 
All subjects achieved oligospermia $\left(<20 \times 10^{6} / \mathrm{ml}\right)$ but not one achieved azoospermia (Fig 3). In this study sperm output was suppressed to $<10 \times 10^{6} / \mathrm{ml}$ in three of ten men, and to $<5 \times 10^{6}$ in one out of ten.
All clinical chemistry and hematology values were within normal limits throughout the study (data not shown).

Table 1. Semen analysis before and during polyester scrotal sling use

\begin{tabular}{clllll}
\hline Weeks & $\begin{array}{c}\text { Volume } \\
\mathrm{ml}\end{array}$ & $\begin{array}{c}\text { Motility } \\
\text { \% motile }\end{array}$ & $\begin{array}{c}\text { Morphology* } \\
\% \text { normal }\end{array}$ & $\begin{array}{c}\text { Velocity* } \\
\text { seconds }\end{array}$ & $\begin{array}{c}\text { Concentration* } \\
\times 10^{6} / \mathrm{ml}\end{array}$ \\
\hline 0 & $3.04(0.63)$ & $77.0(3.21)$ & $57.85(8.95)$ & $1.05(0.05)$ & $80.87(39.64)$ \\
3 & $1.89(0.007)$ & $73.8(8.53)$ & $48.20(16.49)$ & $1.15(0.07)$ & $68.10(48.49)$ \\
6 & $2.49(0.98)$ & $75.7(6.34)$ & $33.20(14.16)$ & $1.13(0.06)$ & $44.03(18.72)$ \\
9 & $2.14(0.70)$ & $71.3(7.85)$ & $20.70(11.68)$ & $1.24(0.10)$ & $40.55(43.67)$ \\
12 & $1.85(0.47)$ & $76.7(6.21)$ & $36.70(16.86)$ & $1.22(0.11)$ & $33.77(23.11)$ \\
15 & $2.07(0.57)$ & $73.2(9.95)$ & $31.90(21.91)$ & $1.19(0.08)$ & $53.85(36.18)$ \\
18 & $1.78(0.49)$ & $77.9(8.82)$ & $20.90(8.53)$ & $1.25(0.04)$ & $23.95(10.41)$ \\
21 & $2.33(1.01)$ & $72.3(5.08)$ & $16.90(6.10)$ & $1.28(0.08)$ & $15.10(4.04)$ \\
24 & $2.18(0.68)$ & $68.8(6.53)$ & $18.80(5.58)$ & $1.26(0.05)$ & $13.31(4.70)$ \\
\hline
\end{tabular}

Value are mean (SD)

* $P$ values for significant difference $(<0.05)$ ANOVA

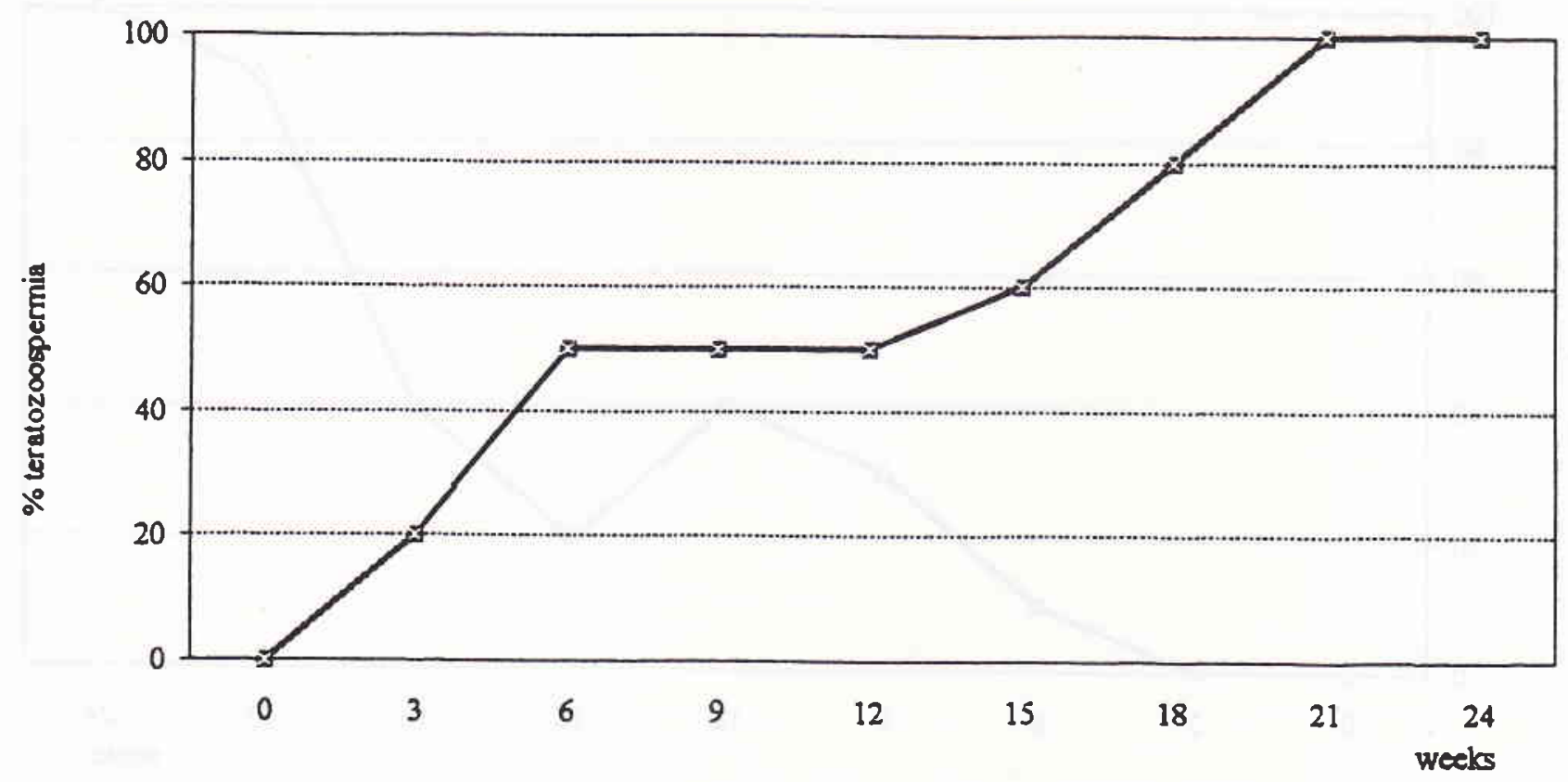

Figure 1. Cumulative rates of terazoospermia (<30\% normal morphology) by time since beginning of polyester scrotal sling use 


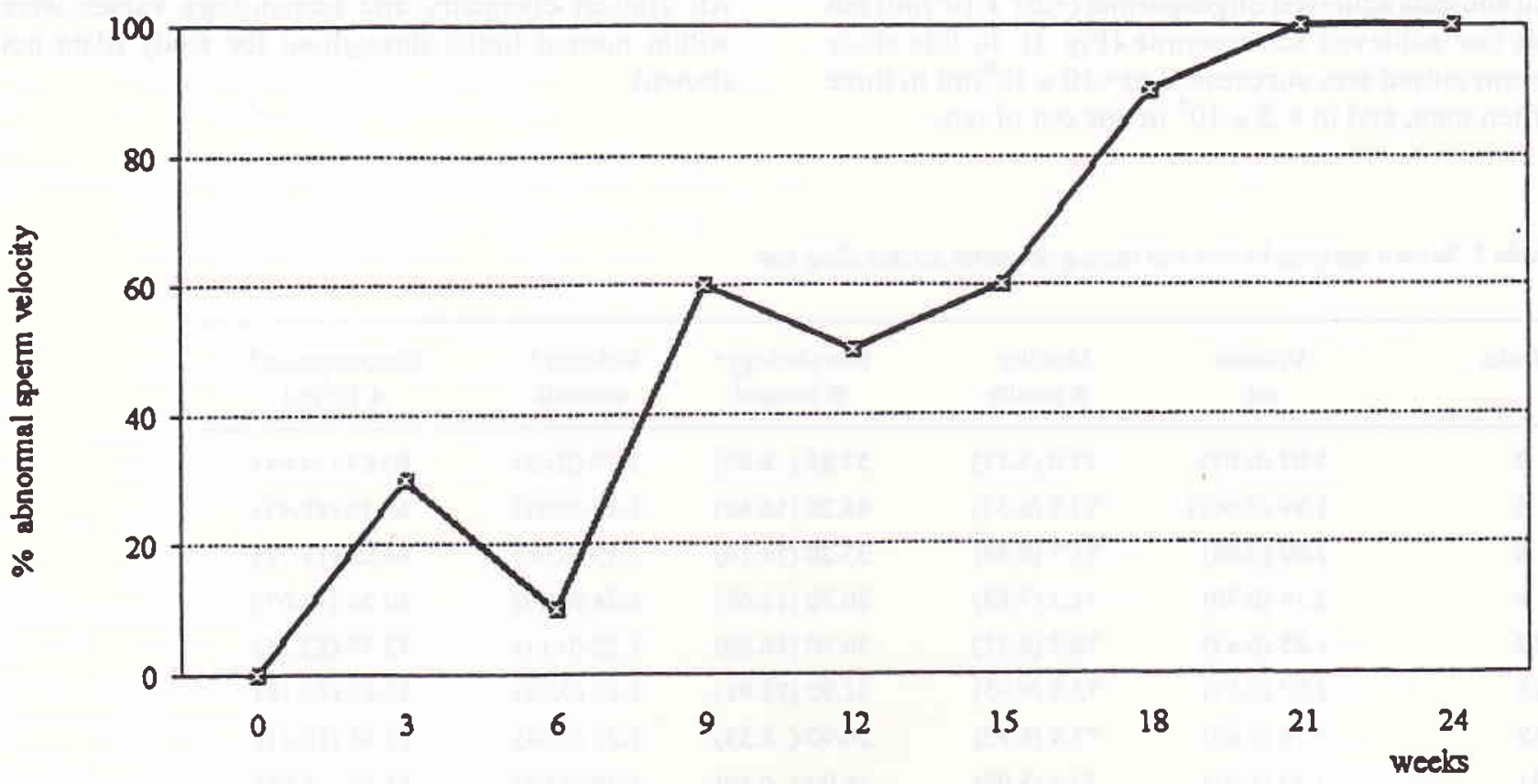

Figure 2. Cumulative rates of abnormal sperm velocity $(<1.20$ seconds) by time since beginning of polyester scrotal sling use

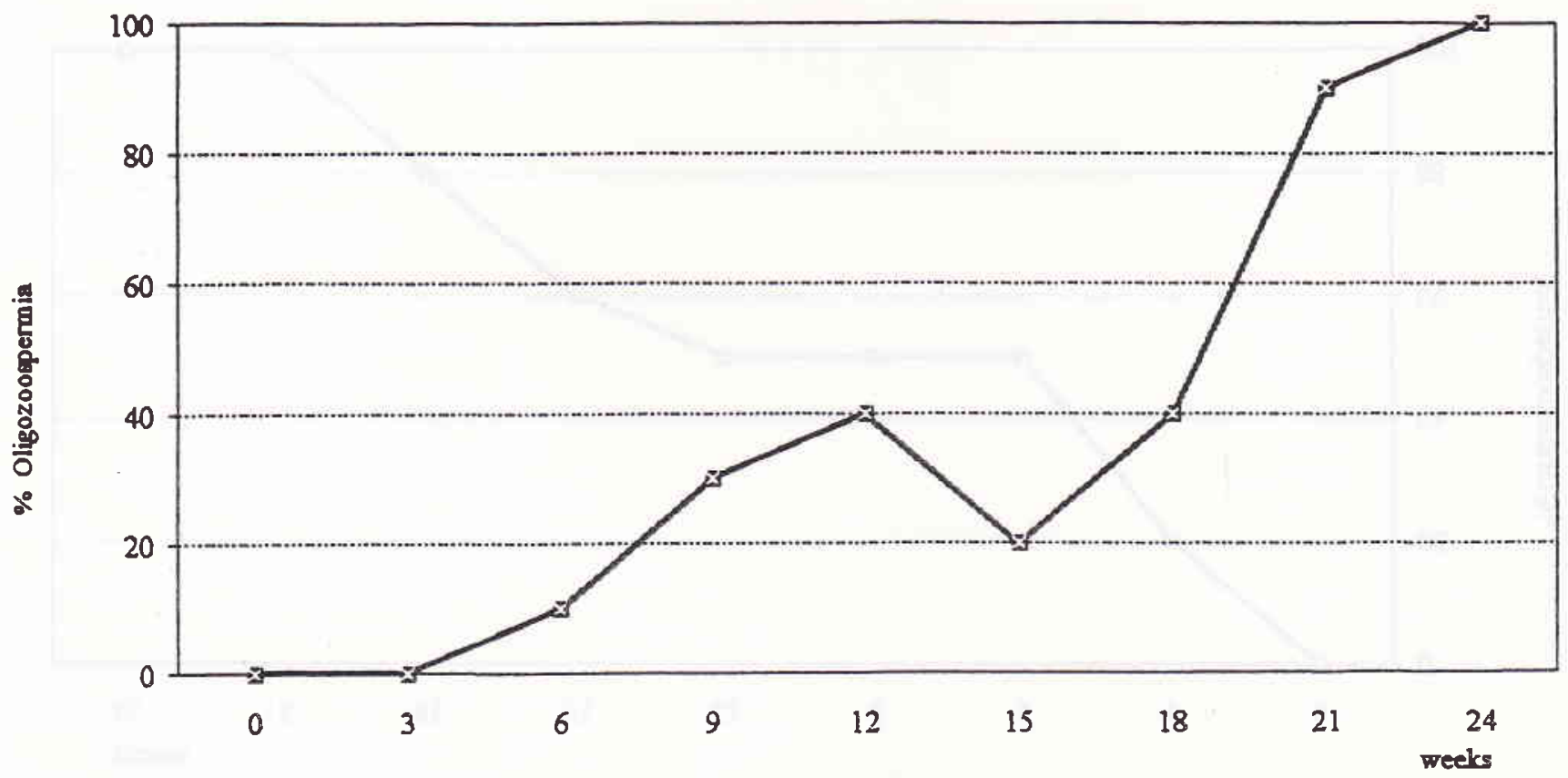

Figure 3. Cumulative rates of suppression to oligozoospermia $\left(<20 \times 10^{6} / \mathrm{ml}\right)$ by time since beginning of polyester scrotal sling use 


\section{DISCUSSION}

This study shows that use of polyester sling scrotal cover was associated with the reduction in sperm velocity, percentage of sperm morphology, and sperm concentration. They all decreased to below normal range of each parameter. The decreasing sperm production has been assumed to be due to the generation of an electrostatic field through the intrascrotal structure, and a thermoregulation disturbance. In the day time the use of $100 \%$ polyester sling generated electrostatic potential of 338.9 (SD 25) V/ $\mathrm{cm}^{2}, 50 / 50 \%$ polyester /cotton, 148.3 (SD 16), and $100 \%$ cotton, 0 $\mathrm{v} / \mathrm{cm}^{2}{ }^{12}$ The electrostatic potential field can influence the $\mathrm{pH}$ and protein in charges in the cell. ${ }^{13,14}$ The use of polyester scrotal sling cover has already proved that testis temperature increased from 34.5 (SD 0,2$)^{\circ} \mathrm{C}$ before using polyester sling to 36.3 (SD 0.4 ) ${ }^{\circ} \mathrm{C}$ while using polyester sling. ${ }^{1}$ The increasing testis temperature can disturb spermatogenesis. ${ }^{15,16}$

All of the ten Indonesian healthy men participated in this study achieved oligospermia, but no one achieved azoospermia, in contrast with those of Egypt study which showed a $100 \%$ azoospermia in 14 men studied. The possible explanation for the differences between Indonesian and Egyptian men may be related to the differences in genetic and environmental factors. The pretreatment sperm concentration of men from Indonesia may be higher than that in Egypt, so that by using the polyester sling scrotal cover for the same period ( 6 months) may not be enough to cause azoospermia in Indonesian men. One environmental factor among others is the temperature difference, where the temperatutre in Egypt is higher than in Indonesia, so that the use of polyester in Egypt is more effective in disturbing the thermoregulation. It has also been proved that in higher temperature, the electrostatic potential is also higher than in the cooler temperature. ${ }^{12}$ Another thing is that the humidity in Indonesia is higher, with the result that the accumulation of electrostatic charges due to the friction of the clothes with the skin is lower because of the sweat due to higher humidity.

Because of all subjects achieved oligospermia within 24 weeks, it is necessary to ascertain whether the use of the polyester sling for a longer period than 24 weeks can achieve azoospermia in Indonesian men. Another point, in order that it can be used as a contraceptive there is no need to achieve azoospermia: the number of fertile spermatozoa in the ejaculate need only be reduced to a sufficient degree to induce consistent infertility. With the decreasing sperm concentration, normal sperm morphology and sperm velocity to below the normal range in all subjects, the achievement of infertile men is still possible. So indeed the function of residual sperm during this polyester lise should be investigated in further study. Shafik ${ }^{1}$ has shown that after removing the polyester sling, the sperm concentration recovered to the pretreatment level took 256.6 (SD 14.8) days. So the use of polyester scrotal sling cover as a safe, effective, reversible, inexpensive, and acceptable male contraceptive is still a possibility.

On the other hand, the use of polyester underwear may be a cause of infertility for married couples.

\section{Acknowledgment}

This work was supported by grant No/P4M/DPPM/L. 3311/94/BBI/1994. Directorate General of Higher Education, Department of Education and Culture, Republic of Indonesia.

\section{REFERENCES}

1. Shafik A. Contraception efficacy of polyester-induced azoospermia in normal men : Contraception 1992; 45 : 439-51.

2. World Health Organization Task Force on Methods for the Regulation on Male Fertility. Contraceptive efficacy of testosterone - induced azoospermia in normal men. Lancet, October 1990; 20, 955-59.

3. Alvarez-Sanches, Faunders A, Brache V, Leon P. Attainment and maintenance of azoospermia with combined monthly injection of depot medroxyprogesterone acetate and testosterone enanthate. Contraception 1977; 15 : 635-47

4. Brenner PF, Mishell DR, Hano R, Gunnarson PO, Nieschlag E. Study of depot medroxyprogesterone acetate and testosterone enanthate as male contraception. Contraception $1977 ; 15: 679-91$.

5. Frick J, Bartsch $\mathbf{G}$ and Weiske WH. The effect of monthly depot medroxyprogesterone acetate and testosterone on human spermatogenesis 1 . Uniform dosage levels. Contraception 1977; $15: 649-67$.

6. Frick J, Danner CH, Kunit G, Joos H, Kohle R. Spermatogenesis in men treated combined with testosterone enanthate. Int J Androl 1982; $5: 246-52$.

7. Melo JF, Coutinlı FM. Inhibition of spermatogenesis in men with monthly injections of medroxyprogesterone acetate and testosterone enanthate.

8. World Health Organization Task Force on Methods for the Regulation of Male Fertility. Comparison of two androgens plus depot-medroxyprogesterone acetate for suppression to azoospernia in Indonesia men. Fertil Steril 1993; 60 : 1062-8.

9. World Health Organization. Laboratory Manual for Examination of Human Semen and Semen Cervical Mucus 
Interaction. 3rd ed. Cambridge University Press, Cambridge; 1992.

10. Farris EJ. Male fertility. Brit Med J 1951; $2: 1475$.

11. Hommonai TZ, Paz FGM. Methods for evaluating contraceptive techniques. In Cunning ham GR, Schill WB, Hafez ESE, eds) : London : Martinus Nyhoff Pbl, 1980; 41 - 54.

12. Shafik A, Ibrahim IH, El Sayed EM. Effect of different types of textile fabric on spermatogenesis : Electrostatic potensials generated on the surface of human scrotum by wearing different types of fabric. Arch Androl 1992; $9: 2$ 147-50.

13. Karshikov AD, Engh R, Bode W, Atanasov BP. Electrostatic interactions in proteins : Calculations of the electrostatic term of frec energy and the electrostatic potential field. Eur Biophys J 1989; 17 : 287-97.

14. Sternberg MJE, Hayes FRF, Rusell AJ, Thomas PG, Fersht AR. Prediction of electrostatic effects of engineering of protein charges. Nature $1987 ; 330: 86-8$.

15. Steinberger E, Dixon WJ. Some observation on the effect of heat on testicular germinal epithelium. Fertil Steril 1985; 10 : 578-95.

16. Cairnie $\mathrm{AB}$, Leach $\mathrm{KE}$. Quantitative studies of cyological damage in mouse testis produced by exposure to heat. Can $\mathrm{J}$ Genet Cytol 1980; 22 : 93-102. 